\title{
Analiza polskich testów do pomiaru inteligencji emocjonalnej lub komponentów składających się na inteligencję emocjonalną
}

\author{
Aleksandra Barbara Lubikowska ${ }^{1}$ \\ lubikowska@gmail.com \\ Uniwersytet im. Adama Mickiewicza \\ w Poznaniu
}

\begin{abstract}
Celem niniejszego badania była weryfikacja korelacji między polskimi testami zadaniowymi służącymi do pomiaru inteligencji emocjonalnej (EI) lub komponentów EI. W badaniu zastosowano Test Inteligencji Emocjonalnej (TIE, Śmieja i Orzechowski, 2008) pozwalający na ocenę ogólnego poziomu EI oraz testy służące do pomiaru zdolności składających się na EI: Skalę Inteligencji Emocjonalnej - Twarze (SIE-T, Matczak, Piekarska i Studniarek, 2005) pozwalającą na ocenę zdolności do rozpoznawania emocji oraz Test Rozumienia Emocji (TRE, Matczak i Piekarska, 2011) umożliwiający ocenę zdolności do rozumienia emocji. W badaniu udział wzięły 43 osoby ze Stowarzyszenia Mensa Polska. Otrzymane wyniki wykazały dodatnią korelację między TRE i TIE $(\mathrm{r}=0,30 \mathrm{p}<0,05)$ oraz ujemną korelację między SIE-T i TRE $(\mathrm{r}=-0,28, \mathrm{p}<0,05)$. Korelacja między SIE-T i TIE okazała się nieistotna.
\end{abstract}

\section{Wprowadzenie teoretyczne}

Inteligencja emocjonalna (emotionalintelligence - EI) to pojęcie stosunkowo nowe w psychologii. Powstało w wyniku rosnącego zainteresowania funkcjonowaniem człowieka w różnych sferach życia: zawodowym, prywatnym czy osiągnięć indywidualnych (Matczak, 2007). Prawdopodobnie po raz pierwszy termin inteligencja emocjonalna pojawił się w 1966 roku $\mathrm{w}$ artykule niemieckiego psychiatry i psychoanalityka Leunera zatytułowanym „Inteligencja emocjonalna i emancypatia" (Leuner, 1966, za: Mayer, Solovey, Caruso, 2004). Wzrost zainteresowania tematyką IE nastąpił jednak dopiero w 1990 roku, kiedy Mayer i Salovey opublikowali dwa artykuły, w których po raz pierwszy podali definicję i określili sposób pomiaru nowego rodzaju inteligencji.

\footnotetext{
${ }^{1}$ Artykuł został napisany na podstawie pracy magisterskiej pt. „Sprawność wykorzystywania inteligencji emocjonalnej u osób o wysokim ilorazie inteligencji ogólnej" napisanej w Instytucie Psychologii UAM pod kierunkiem prof. dr hab. Władysława Paluchowskiego i recenzowanej przez prof. dr hab. Elżbietę Hornowską.
} 


\section{Model inteligencji emocjonalnej autorstwa Saloveya i Mayera}

Mimo iż zainteresowanie koncepcją inteligencji emocjonalnej trwa od przeszło dwudziestu lat, wciąż nie została wypracowana spójna definicja tego pojęcia. Przyjmowanych jest wiele wyjaśnień omawianego konstruktu, niektóre z nich znacząco się od siebie różnią, inne są zbliżone lub wzajemnie się uzupełniają (Taracha, 2010). Inteligencja emocjonalna bywa traktowana jako zdolność (ability EI, np. w modelu Saloveya i Mayera, 1990), cecha, kompetencja, postawa lub umiejętność (np. w koncepcji Golemana, 1997; Petridesa i Furnhama, 2000).

W niniejszym badaniu odwołano się do pierwszego i, zdaniem autorki, najbardziej spójnego modelu inteligencji emocjonalnej, który został stworzony przez Saloveya i Mayera (1990).W modelu wspomnianych badaczy inteligencja emocjonalna traktowana jest jako „umiejętność właściwej percepcji, oceny i wyrażania emocji, umiejętność dostępu do uczuć, zdolność do generowania ich w momentach, gdy mogą wspomóc myślenie, umiejętność rozumienia emocji i zrozumienie wiedzy emocjonalnej, oraz umiejętność regulowania emocji tak, by wspomagać rozwój emocjonalny i intelektualny” (Salovey i Mayer, 1997, str. 34). Zgodnie z omawianą teorią EI oznacza zdolność jednostki do myślenia o emocjach i przetwarzania informacji emocjonalnych w celu wspomagania procesów poznawczych. Wyliczone w definicji umiejętności łączą się w cztery główne grupy komponentów (branches) składających się z bardziej szczegółowych zdolności. Wyodrębnione przez autorów grupy to: postrzeganie emocji, wykorzystywanie emocji w celu wspomagania procesów myślenia, rozumienie emocji oraz zarządzanie emocjami. Jak przedstawiono na rysunku 1, zdolności wyróżnione w modelu są ułożone hierarchicznie - od zdolności podstawowych (np. rozpoznawanie emocji) na dole modelu, do bardziej zaawansowanych umiejętności (np. regulacja emocji), znajdujących się na górze. Warunkiem koniecznym do rozwinięcia się zdolności złożonych jest posiadanie przez człowieka zdolności podstawowych.

\section{Pomiar EI: testy zadaniowe a kwestionariusze samoopisowe}

Konsekwencje przedstawionego powyżej rozróżnienia definicji IE są szczególnie widoczne w sposobie operacjonalizacji omawianego konstruktu. Zwolennicy traktowania EI jako zbioru zdolności - nawiązując do tradycyjnych metod badania inteligencji ogólnej koncentrują się na stworzeniu obiektywnych testów zadaniowych. Natomiast za pomiarem 
kwestionariuszami samoopisowymi opowiadają się badacze traktujący IE jako cechę. Najpopularniejszym i najbardziej wszechstronnym testem zadaniowym do oceny EI jest Mayer Salovey - Caruso Emotional Intelligence Test (MSCEIT) autorstwa Mayera, Saloveya i Caurso (2002). Do najbardziej znanych testów samoopisowych można zaliczyć Schutte Self-Report Inventory (SSRI) autorstwa Schutte i innych (1998) oraz Bar - On Emotional Quotient Inventory (EQ-i) autorstwa Bar - Ona (1997b). Opis najbardziej znanych zagranicznych metod pomiaru EI można znaleźć w artykule pt. „Measuring Trait Emotional Intelligence” autorstwa Pereza, Petridesa i Furnhama (2005).

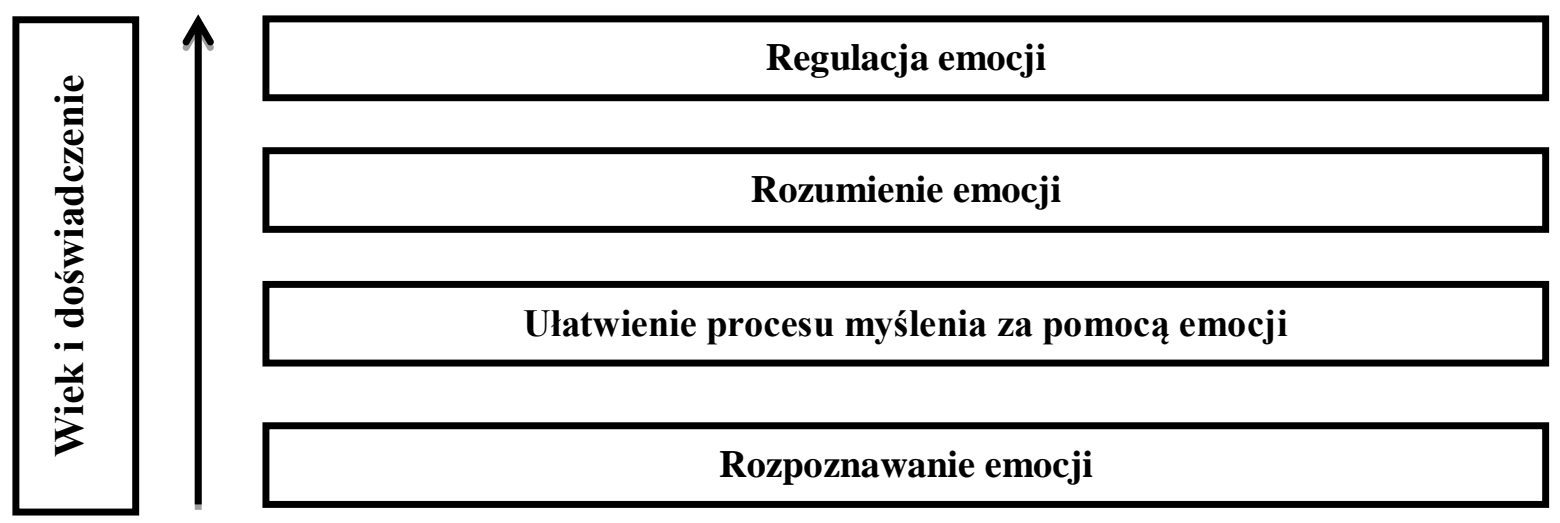

Rys. 1. Model inteligencji emocjonalnej w koncepcji Saloveya i Mayera

Źródło: Opracowanie własne na podstawie Mayer, Salovey (1997).

W Polsce dostępnych jest pięć metod służących do pomiaru inteligencji emocjonalnej lub jej komponentów. Są to dwa kwestionariusze samoopisowe: Popularny Kwestionariusz Inteligencji Emocjonalnej (PKIE) autorstwa Jaworowskiej, Matczak, Ciechanowicz, Stańczak oraz Zalewskiej (2005) oraz polska adaptacja SSRI pod nazwą Kwestionariusz Inteligencji Emocjonalnej (INTE) autorstwa Ciechanowicz, Jaworowskiej i Matczak (2008). Spośród metod zadaniowych w Polsce dostępne są: Test Inteligencji Emocjonalnej (TIE) autorstwa Śmiei i Orzechowskiego (2007), Skala Inteligencji Emocjonalnej - Twarze (SIE-T) służąca do pomiaru zdolności do rozpoznawania emocji, autorstwa Matczak, Piekarskiej i Studniarek (2005) oraz Test Rozumienia Emocji (TRE) pozwalający na pomiar zdolności do rozumienia emocji, autorstwa Matczak i Piekarskiej (2011). Charakterystykę polskich metod pomiaru EI można znaleźć w książce pt. „Inteligencja emocjonalna. Fakty, mity, kontrowersje” autorstwa Śmiei i Orzechowskiego (2008). 
Metody pomiaru EI wciąż budzą kontrowersje. Badacze są niezgodni w kwestii tego co testy i kwestionariusze EI właściwie mierzą, jakie zachowania można przewidywać na podstawie wyników oraz czy narzędzia służące do pomiaru EI mierzą coś innego niż cechy osobowości (Brackett i Mayer, 2003). Wyniki w kwestionariuszach samoopisowych odzwierciedlają przekonanie osób badanych na temat posiadanych przez te osoby zdolności. Jeśli samoocena i samowiedza danej osoby jest właściwa, wówczas metody samoopisowe będą stanowiły dobrą formę pomiaru EI. Jednakże należy zwrócić uwagę, iż w licznych badaniach stwierdzana jest nieadekwatna samoocena osób badanych w zakresie EI (np. Brackett, Rivers, Shiffman, Lerner i Salovey, 2006; Zeidner, Shani-Zinovich, Matthews i Roberts, 2005; Lubikowska, 2013).

W większości badań korelacje między testami zadaniowymi i samoopisowymi są zazwyczaj niskie (Barchard i Hakstian, 2004; Brackett, Rivers, Lerner, Salovey i Shiffman, 2006; Rivers, 2005; Goldenberg, Matheson, Mantler, 2006), co wskazuje, że podczas rozwiązywania omawianych testów aktywowane są inne procesy umysłowe. Na przykład, Brackett i Mayer (2003) przeprowadzili badanie, w którym analizowali korelacje między testem MSCEIT oraz kwestionariuszami EQ-i i SREIT. Otrzymane wyniki ukazały iż, MSCEIT słabo korelował z metodami samoopisowymi ( $r=0,21$ z EQ-i oraz $r=0,18$ z SREIT). Podobne wyniki otrzymano w dwóch innych badaniach, w których porównywano korelacje między testem MSCEIT a kwestionariuszem SSRI (Zeidner, Shani-Zinovich, Matthews i Roberts, 2005) oraz między MSCEIT i kwestionariuszem SREIS (Brackett, Rivers, Lerner, Salovey i Shiffman, 2006). Natomiast gdy we wspomnianym badaniu Bracketta i Mayera (2003) analizom poddano korelacje między kwestionariuszami. Okazały się one umiarkowane, $r=0,43$. Ponadto, stwierdzono niskie korelacje MSCEIT z użytymi w badaniu metodami do pomiaru osobowości i dobrostanu. Wykazano również umiarkowane korelacje między MSCEIT a otwartością, ugodowością, psychologicznym dobrostanem i inteligencją ogólną (od r=0,25 do r=0,32). W przypadku kwestionariuszy EI stwierdzono silne korelacje z testami osobowości, co jest zgodne z wynikami wielu innych badań (np. Bar-On, 1997b; Dawda i Hart, 2000; Newsome i in., 2000; Schuttei in., 1998).

Matczak i Piekarska (2011) opisały wyniki badań, w których analizowano korelacje między polskimi testami i kwestionariuszami służącymi do pomiaru EI lub komponentów składających się EI. Wykazano umiarkowane korelacje między testem TRE a testami SIE-T, MEIS, kwestionariuszem INTE oraz kwestionariuszem DINEMO. Ponadto, stwierdzono umiarkowane korelacje między testem SIE-T a testami TRE i MEIS w grupie studentów 
i osób dorosłych (Matczak, Piekarska i Studniarek, 2005). Nie wykazano z kolei korelacji między testem SIE-T i kwestionariuszem INTE, co jest zgodne z opisanymi powyżej wynikami badań świadczącymi o braku lub niskich korelacjach między metodami testowymi i samoopisowymi służącymi do pomiaru EI.

Celem niniejszego badania była analiza korelacji między polskimi zadaniowymi testami służącymi do pomiaru EI lub komponentów składających się na inteligencję emocjonalną. Na podstawie opisanych powyżej wyników badań, w których analizowano korelacje między zadaniowymi testami EI oraz biorąc pod uwagę, iż wszystkie testy służą do pomiaru inteligencji emocjonalnej lub komponentów EI oczekiwano umiarkowanych korelacji między zastosowanymi metodami.

\section{Badania własne}

\section{Metoda}

Przyjęcie modelu teoretycznego zaproponowanego przez Saloveya i Mayera (1999) przyczyniło się do wyboru metod zastosowanych w badaniu. Wszystkie testy użyte w badaniu miały charakter zadaniowy, gdyż taki pomiar ogólnego poziomu EI oraz komponentów EI uznano za najbardziej obiektywny.

Podstawowym założeniem, którym kierowano się przy wyborze metod było mierzenie rzeczywistych zdolności osób biorących udział w badaniu, a nie ich przekonań na własny temat. Badanie Bracketta i współpracowników (2006) pokazuje, iż większość ludzi jest przekonana, że ich inteligencja emocjonalna jest wyższa od przeciętnej, trudno jest więc mówić o rzetelnej samoocenie badanych w kwestionariuszach. W związku z powyższym wszystkie użyte w badaniu narzędzia, choć opierały się na różnym materiale, były testami zadaniowymi a nie samoopisowymi.

W badaniu zastosowano trzy następujące testy zadaniowe służące do pomiaru inteligencji emocjonalnej lub komponentów EI:

Test Inteligencji Emocjonalnej (TIE, Śmieja i Orzechowski, 2007) pozwalający na ocenę ogólnego poziomu inteligencji emocjonalnej badanej osoby oraz poziom zdolności stanowiących poszczególne komponenty IE, wyróżnione w modelu Saloveya i Mayera (1997). TIE składa się z 24 zadań podzielonych na dwie podskale odpowiadające wyróżnionym w modelu grupom zdolności: percepcji i rozumieniu emocji (1 część) oraz zdolności asymilacji i zarządzania emocjami (2 część). W pierwszej części osoba badana ma wskazać co czuli i myśleli 
bohaterowie opisanych sytuacji. Zadaniem uczestnika jest ocenienie, na ile prawdopodobne jest to, iż przeżywali oni określone emocje. W drugiej części testu osoba badana ma oszacować, jakie postępowanie bohaterów danej sytuacji byłoby najskuteczniejsze oraz jakie emocje sprzyjałyby a jakie przeszkadzały w wykonaniu opisanych zadań. W obu częściach testu, oceny dokonuje się na 5-stopniowej skali Likerta, gdzie 1 oznacza odpowiedź bardzo złą, zaś 5 bardzo dobrą. Normy do testu TIE zostały utworzone na podstawie badań 4041 osób, z których 2664 stanowiły kobiety, zaś 1673 mężczyźni. Średnia wieku osób z próby normalizacyjnej to 25,5 lat.

Narzędzie charakteryzuje się dobrymi własnościami psychometrycznymi (Śmieja, Orzechowski i Asanowicz, 2012).

Skala Inteligencji Emocjonalnej - Twarze (SIE-T, Matczak, Piekarska i Studniarek, 2005) służy do oceny jednej ze zdolności składających się na EI - percepcję emocji. SIE - T tworzy zestaw 18 zdjęć, na połowie z nich widnieje twarz kobiety, na drugiej połowie twarz mężczyzny. Twarze osób na fotografiach wyrażają 8 pozytywnych stanów emocjonalnych (4 prezentuje kobieta, 4 prezentuje mężczyzna) oraz 10 negatywnych emocji (5 prezentuje mężczyzna i 5 prezentuje kobieta). Do każdej fotografii na arkuszu odpowiedzi przypisanych jest zestaw sześciu nazw emocji zarówno pozytywnych jak i negatywnych. Osoba badana ma każdorazowo ustosunkować się, czy osoba na fotografii wyraża wypisane emocje i zaznaczyć jedną $\mathrm{z}$ trzech możliwości odpowiedzi: wyraża, nie wyraża lub trudno powiedzieć. Wszystkie wypisane obok fotografii emocje tworzą odrębne pozycje testowe, w związku z czym łączna liczba pozycji wynosi 108. Podłoże teoretyczne testu stanowi koncepcja IE autorstwa Saloveya i Mayera (1999).

Test posiada bardzo dobre właściwości psychometryczne (Matczak, Piekarska i Studniarek, 2005).

Test Rozumienia Emocji (TRE, Matczak, Piekarska, 2011) pozwalający na pomiar jednego ze składników EI - zdolności rozumienia emocji. TRE składa się z 30 zadań pogrupowanych w 5 odrębnych części testu. W pierwszej części osoba badana ma uszeregować wypisane emocje w kolejności od najsłabszej do najsilniejszej emocji (np. zachwyt, ekstaza, wściekłość, rozdrażnienie), zaś w pozostałych częściach należy wybrać poprawną odpowiedź spośród czterech podanych możliwości. W części drugiej osoba badana ma za zadanie wybrać emocję przeciwną do wskazanej w instrukcji (np. wskazanie emocji przeciwnej do pogardy spośród: fascynacji, podziwu, sympatii, uznania). W trzeciej części zadanie osoby badanej polega na wskazaniu emocji prostszych, które stanowią nieodzowne składniki określonych stanów, czy 
emocji złożonych (np. miłość - niepewność, podziw, akceptacja, radość). W kolejnej części osoba badana proszona jest o wskazanie w poszczególnych zadaniach emocji, która $\mathrm{z}$ największym prawdopodobieństwem pojawi się w danej sytuacji (np. niespodzianka - wdzięczność, radość, zaskoczenie, nieufność). W ostatniej części opisana jest sytuacja i reakcja emocjonalna na nią, zadaniem osoby badanej jest znaleźć okoliczność warunkującą wystąpienie podanej reakcji emocjonalnej (np. uzyskana oferta pomocy może budzić złość, jeżeli człowiek - czuje się bezradny, zbyt wysoko ocenia swoje możliwości, czuje się zagubiony, jest nieufny). Podłoże teoretyczne testu stanowi koncepcja IE autorstwa Saloveya i Mayera (1999).

Test posiada bardzo dobre właściwości psychometryczne (Matczak i Piekarska, 2011).

\section{Procedura badania}

W badaniu udział wzięły 43 osoby (60\% mężczyzn, 40\% kobiet) przynależące do Stowarzyszenia Mensa Polska zrzeszającego osoby o ilorazie inteligencji mieszczącym się w dwóch górnych procentach populacji. Biorąc pod uwagę wyniki badań świadczące o wzroście poziomu inteligencji emocjonalnej wraz z wiekiem (np. m.in. Mayer, Salovey, Carus i Sitarenios, 2001; Derksen, Kramer i Katzko, 2000) postanowiono, aby grupę badawczą stanowiły osoby w zbliżonym wieku. W związku z powyższym, uczestnikami badania były osoby $\mathrm{w}$ okresie wczesnej dorosłości, od 21 do 30 roku życia $(\mathrm{M}=25$, $\mathrm{SD}=3,2)$ (Boyd i Bee, 2004).

\section{Uzyskane wyniki}

Wartości statystyk opisowych dla wyniku ogólnego w teście TIE oraz poszczególnych komponentów inteligencji emocjonalnej mierzonych za pomocą Testu Inteligencji Emocjonalnej, Skali Inteligencji Emocjonalnej - Twarze oraz Testu Rozumienia Emocji przedstawia tabela 1 .

$\mathrm{Na}$ podstawie wyników przedstawionych w powyższej tabeli należy stwierdzić, że osoby biorące udział w badaniu osiągnęły zarówno wyższe wyniki ogólne w zakresie EI, jak i wyniki dla poszczególnych komponentów EI w porównaniu z wynikami ogólnymi w populacji. Otrzymane wyniki są zgodne z wynikami wielu innych badań, w których badano EI u osób wybitnie zdolnych (min. Terman, 1925; Zeidner, Shani-Zinovich, Matthews i Roberts, 2005; Parker, 1996; Nail i Evans, 1997). 
Tabela 1. Średnie wyniki i odchylenia standardowe w badanej próbie i w populacji polskiej.

\begin{tabular}{|c|c|c|c|c|c|}
\hline Zmienna & $\mathbf{N}$ & $\begin{array}{l}\text { M w ba- } \\
\text { danie pró- } \\
\text { bie }\end{array}$ & $\begin{array}{l}\text { M w po- } \\
\text { pulacji }\end{array}$ & $\begin{array}{l}\text { SD w ba- } \\
\text { danej } \\
\text { próbie }\end{array}$ & $\begin{array}{l}\text { SD w po- } \\
\text { pulacji }\end{array}$ \\
\hline $\begin{array}{l}\text { TIE - wy- } \\
\text { nik ogólny }\end{array}$ & 43 & 31,23 & 28,03 & 3,94 & 5,24 \\
\hline TIE-1 & 43 & 8,69 & 7,75 & 1,30 & 1,78 \\
\hline SIE-T & 43 & $\begin{array}{l}\text { Kobiety: } \\
77,52 \\
\text { Mężczyźni: } \\
80,77\end{array}$ & $\begin{array}{l}\text { Kobiety: } \\
73,05 \\
\text { Mężczyźni: } \\
72,16\end{array}$ & $\begin{array}{l}\text { Kobiety: } \\
6,39 \\
\text { Mężczyźni: } \\
5,47\end{array}$ & $\begin{array}{l}\text { Kobiety: } \\
12,37 \\
\text { Mężczyźni: } \\
12,08\end{array}$ \\
\hline TIE-2 & 43 & 8,06 & 7,15 & 1,21 & 1,64 \\
\hline TRE & 43 & $\begin{array}{l}\text { Kobiety: } \\
21,77 \\
\text { Mężczyźni: } \\
20,54\end{array}$ & $\begin{array}{l}\text { Kobiety: } \\
17,55 \\
\text { Mężczyźni: } \\
16,20\end{array}$ & $\begin{array}{l}\text { Kobiety: } \\
3,42 \\
\text { Mężczyźni: } \\
3,08\end{array}$ & $\begin{array}{l}\text { Kobiety: } \\
3,93 \\
\text { Mężczyźni: } \\
4,37\end{array}$ \\
\hline TIE-3 & 43 & 7,55 & 6,82 & 1,30 & 1,55 \\
\hline TIE-4 & 43 & 6,93 & 6,30 & 1,26 & 1,43 \\
\hline
\end{tabular}

TIE - Test Inteligencji Emocjonalnej; TIE - 1 - Test Inteligencji Emocjonalnej, podskala rozpoznawanie emocji, TIE - 2 - Test Inteligencji Emocjonalnej, podskala rozumienie emocji, TIE - 3 - Test Inteligencji Emocjonalnej, podskala asymilacja emocji, TIE - 4 - Test Inteligencji Emocjonalnej, podskala zarządzanie emocjami, SIE-T - Skala Inteligencji Emocjonalnej - Twarze, TRE - Test Rozumienia Emocji.

Źródło: Opracowane na podstawie wyników badań własnych oraz Śmieja, Orzechowski, Asanowicz (2012), Matczak, Piekarska (2011), Matczak, Piekarska, Studniarek (2005).

Rozkład wyników we wszystkich trzech testach jest rozkładem normalnym (test Kołmogorowa-Smirnowa: $Z=0,627, p=0,827$ w teście SIE-T, $Z=0,626, p=828$ w teście TRE oraz $\mathrm{Z}=0,630, \mathrm{p}=0,823 \mathrm{w}$ teście TIE). Analizy korelacji między wynikami otrzymanymi w testach dokonano z zastosowaniem korelacji $r$ Pearsona. Otrzymane wyniki zostały zaprezentowane w tabeli 2.

Tabela 2. Korelacje ( $r$ Pearsona) między wynikam i w testach.

\begin{tabular}{|l|l|l|}
\hline & SIE-T & TRE \\
\hline TIE & $-0,22$ & $0,30^{*}$ \\
\hline TIE-rozpoznawanie emocji & $-0,25^{*}$ & - \\
\hline TIE-rozumienie emocji & - & $0,29^{*}$ \\
\hline SIE-T & - & $-0,28^{*}$ \\
\hline
\end{tabular}

* - oznacza istotność na poziomie $\mathrm{p}<0,05$

Otrzymano ujemną korelację między SIE-T i TRE. Z kolei niska pozytywna korelacja została wykazana między TRE i TIE. 
W celu pogłębienia analizy weryfikowano korelacje między wynikami w teście TIE otrzymane dla komponentu EI - rozpoznawanie emocji oraz testu SIE-T służącego do oceny zdolności do rozpoznawania emocji. Otrzymane wyniki wykazały ujemną korelację między wynikami we wspomnianych testach. Ponadto, sprawdzono korelacje między wynikami w teście TRE otrzymane dla komponentu EI - rozumienie emocji oraz testu TRE pozwalającemu na ocenę zdolności do rozumienia emocji. Wykazano niską dodatnią korelację między wynikami osiągniętymi w testach.

\section{Dyskusja}

W niniejszym badaniu analizie poddano korelacje między trzema polskimi testami zadaniowymi: Testem Inteligencji Emocjonalnej, który służy do pomiaru ogólnego poziomu EI, Testem Rozumienia Emocji, który bada zdolność do rozumienia emocji oraz Skalą Inteligencji Emocjonalnej - Twarze umożliwiającą pomiar zdolności do rozpoznawania emocji.

$\mathrm{Na}$ podstawie opisanego we wstępie artykułu przeglądu badań założono, iż wyniki otrzymane w testach będą korelowały co najmniej na umiarkowanym poziomie. Założona hipoteza potwierdziła się częściowo. Główne rezultaty z przeprowadzonego badania są następujące:

1) wykazano pozytywne korelacje między Testem Rozumienia Emocji oraz Testem Inteligencji Emocjonalnej (zarówno wynik ogólny jak i wynik dla zdolności do rozumienia emocji), co jest zgodne z wynikami badań wskazującymi na pozytywne korelacje między zadaniowymi metodami służącymi do pomiaru EI (Matczak, Piekarska i Studniarek, 2005; Matczak i Piekarska, 2011).

2) w badanej próbie nie stwierdzono pozytywnych korelacji między Skalą Inteligencji Emocjonalnej - Twarze a pozostałymi zastosowanymi metodami.

Ujemne korelacje między SIE-T a TRE mogą wynikać z faktu, iż oba testy służą do pomiaru różnych komponentów EI (SIE-T - zdolność do rozpoznawania emocji, TRE - zdolność do rozumienia emocji). Jak wskazują autorki Testu Rozumienia Emocji (Matczak i Piekarska, 2011, str. 14) podstawowymi komponentami wiedzy o emocjach ocenianymi w teście są ,znajomość nazw określających emocje, wiedza o relacjach między emocjami, wiedza o zmianach zachodzących w toku nasilenia się emocji oraz wiedza o źródłach emocji”. Choć w Skali Inteligencji Emocjonalnej - Twarze od osoby badanej wymagana jest znajomość nazw emocji to warto zwrócić uwagę, iż test służy do rozpoznawania ekspresji mimicznej osób widniejących na fotografiach. Różnica w materiale testowym mogła wpłynąć na negatywne 
korelacje wyników osób badanych w testach. Należy bowiem podkreślić, iż w żadnym z zadań Testu Rozumienia Emocji nie jest angażowana zdolność do rozpoznawania emocji.

Podobne przyczyny mogły wpłynąć na otrzymanie negatywnych korelacji między SIE-T a TIE (zarówno wynikiem ogólnym w teście TIE oraz wynikami dla komponentu rozpoznawanie emocji, który jest mierzony w teście SIE-T). W TIE osoba badana na podstawie opisu historyjek ocenia występowanie u bohaterów różnych emocji. W żadnej z części TIE zadaniem osoby badanej nie jest rozpoznanie emocji na materiale niewerbalnym. Różnica w materiale badawczym, na podstawie którego oceniana jest zdolność do rozpoznawania emocji w SIE-T i TIE, mogła mieć wpływ na osiągnięte wyniki.

Ujemne korelacje między SIE-T i pozostałymi testami użytymi w badaniu mogłyby wskazywać na niską trafność teoretyczną testu. Należy jednak podkreślić, iż w badaniach normalizacyjnych SIE-T otrzymano pozytywne korelacje z innymi zadaniowymi metodami służącymi do pomiaru EI, co przemawia za trafnością testu.

Wyniki opisywanego badania wskazujące pozytywną korelacja między Testem Rozumienia Emocji z wynikiem ogólnym Testu Inteligencji Emocjonalnej, jak i z podskalą rozumienie emocji TIE dostarczyły nowych, ważnych informacji. Otrzymane w badaniu dane stanowią bowiem kolejny argument potwierdzający trafność teoretyczną, zarówno Testu Rozumienia Emocji, jak i Testu Inteligencji Emocjonalnej. Warto byłoby przeprowadzić kolejne badania w celu analizy korelacji między wspomnianymi testami z grupą osób losowo dobranych osób badanych.

Interesujące byłoby porównanie wyników otrzymywanych przez osoby badane w zadaniowych testach EI do wyników osiąganych np. w różnych badaniach eksperymentalnych czy sytuacjach społecznych. Wyniki omawianego badania wskazują, iż materiał badawczy może wpływać na wyniki dla poszczególnych zdolności składających się na inteligencję emocjonalną. Warto sprawdzić czy osoby, które potrafią dobrze rozpoznawać emocje np. na fotografiach równie dobrze poradzą sobie z weryfikacją emocji na materiale słuchowym czy np. na filmie czy w codziennych rzeczywistych sytuacjach. Ułatwienie procesu myślenia za pomocą emocji czy regulacja emocji są to zdolności niezwykle przydatne i wykorzystywane w życiu codziennym. Warto byłoby zweryfikować czy wyniki osiągane w testach zadaniowych przez uczestników badań przekładają się na ich poziom zdolności do wykorzystywania wymienionych zdolności w życiu codziennym, np. w przygotowanych odpowiednio sytuacjach eksperymentalnych. 


\section{Literatura cytowana}

Barchard, K. A., Hakstian, A. R. (2004). The nature and measurement of emotional intelligence abilities: Basic dimensions and their relationships with other cognitive ability and personality variables. Educational and Psychological Measurement, 64, 437-462.

Bar-On, R. (1997). Bar-On Emotional Quotient Inventory (EQ-i): Technical manual. Toronto, Canada: Multi-Health Systems.

Boyd, D. Bee, H. (2006). Lifespan Development. Boston: Allyn i Bacon.

Brackett, M. A., Mayer, J. D. (2003). Convergent, discriminant, and incremental validity of competing measures of emotional intelligence. Personality and Social Psychology Bulletin, 29, 11471158.

Brackett, M. A., Rivers, S. R., Lerner, N., Salovey, P.,Shiffman, S. (2006). Relating emotional abilities to social functioning: A comparison of self-report and performance measures of emotional intelligence. Journal of Personality and Social Psychology, 4, 780-795.

Darksen, J., Kramer, I. Katzko, M. (2009). Does a self-report measure for emotional intelligence assess something different then general intelligence. Personality and Individual Differences, 32, $37-48$.

Dawda, D., Hart, S. D. (2000). Assessing emotional intelligence: Reliability and validity of the Bar-On Emotional Quotient Inventory (EQ-i) in university students. Personality and Individual Differences, 28, 797-812.

Goldenberg, I., Matheson, K., Mantler, J. (2006). The Assessment of Emotional Intelligence: A Comparison of Performance-Based and Self-Report Methodologies. Journal of PersonalityAssessment, 86, 33-45.

Goleman, D. (1997). Inteligencja emocjonalna. Poznań: Media Rodzina.

Jaworowska, A., Matczak, A. (2005). PKIE - Popularny Kwestionariusz Inteligencji Emocjonalnej. Podręcznik. Warszawa: Pracownia Testów Psychologicznych Polskiego Towarzystwa Psychologicznego.

Lubikowska, A. (2013). Sprawność wykorzystywania inteligencji emocjonalnej u osób o wysokim poziomie inteligencji ogólnej. Niepublikowana praca magisterska. Poznań: Uniwersytet im. Adama Mickiewicza, Instytut Psychologii.

Matczak, A. (2007). Rola inteligencji emocjonalnej. Studia Psychologiczne, 45, 9-17.

Matczak, A., Piekarska, J. (2011). Test Rozumienia Emocji (TRE). Podręcznik. Warszawa: Pracownia Testów Psychologicznych Polskiego Towarzystwa Psychologicznego.

Matczak, A., Piekarska, J., Studniarek, E. (2005). Skala Inteligencji Emocjonalnej - Twarze (SIE-T). Podręcznik. Warszawa: Pracownia Testów Psychologicznych Polskiego Towarzystwa Psychologicznego.

Mayer, J. D.,Salovey, P. (1997). What is emotional intelligence? W: P. Salovey, D. Sluyter (red.), Emotional development and EI: Educational implications (str. 3-34). New York: Basic Books. 
Mayer, J. D., Salovey, P., Caruso, D. (2002). Mayer-Salovey-Caruso Emotional Intelligence Test: User's manual. Toronto, Ontario, Canada: Multi-Health Systems.

Mayer, J. D., Salovey, P., Caruso, D. (2004). Emotional intelligence: Theory, findings and implications. Psychological Inquiry, 15, 197-215.

Mayer, J.D., Salovey, P., Caruso, P.,Sitarenios, G. (2001). Emotional Intelligence as a Standard Intelligence. Emotion, 3, 232-242.

Nail, J. M., Evans, J. G. (1997). The emotional adjustment of gifted adolescents: A view of global functioning. Roeper Review, 20, 18-21.

Newsome, S., Day, A. L.,Catano, V.M. (2000). Assessing the predictive validity of emotional intelligence. Personality and IndividualDifferences, 29, 1005-1016.

Parker, W. D. (1996). Psychological adjustment in mathematically gifted students. Gifted Child Quarterly, 40, 154-157.

Pérez, J. C., Petrides, K. V., Furnham, A. (2005). Measuring trait emotional intelligence. W: R. Schulze and R. D. Roberts (red.), International Handbook of Emotional Intelligence. Cambridge, MA: Hogrefei Huber.

Petrides, K.V.Furnham, A. (2000). Gender differences in measured and self-estimated trait emotional intelligence. Sex Roles , 42, 449-461.

Rivers, S. (2005). Measurement issues in emotional intelligence research: Predicting social outcomes. Paper presented at the annual meeting of the Society of Personality and Social Psychology, New Orleans, LA.

Salovey, P., Mayer, J. D. (1990). Emotional intelligence. Imagination, Cognition, and Personality, 9, $185-211$.

Schutte, N. S.,Malouff, J.M., Hall, L. E., Haggerty, D. J., Cooper, J. T., Golden, C. J., et al. (1998). Development and validation of a measure of emotional intelligence. Personality and Individual Differences, 25, 167-177.

Śmieja, M., Orzechowski, J. (2008). Inteligencja emocjonalna. Fakty, mity, kontrowersje. Warszawa: PWN.

Śmieja, M., Orzechowski, J. Asanowicz, D. (2012). Test Inteligencji Emocjonalnej (TIE). Podręcznik. Kraków: Wszechnica Uniwersytetu Jagiellońskiego.

Szczygieł, D. (2008). Inteligencja emocjonalna - więcej niż IQ i osobowość? O potrzebie i znaczeniu sprawdzania trafności dodanej narzędzi mierzących inteligencję emocjonalną. W: M. Śmieja, J. Orzechowski (red.). Inteligencja emocjonalna. Fakty, mity, kontrowersje (str. 136-152). Warszawa: PWN.

Taracha, M. (2010). Inteligencja emocjonalna a wykorzystanie potencjatu intelektualnego.Lublin: WydawnictwoUniwersytetuMarii Curie - Skłodowskiej.

Terman, L. M. (1925). Mental and physical traits of a thousand gifted children. Stanford, CA: Stanford University Press.

Zeidner, M., Shani - Zinovich, I., Matthews, G. Roberts, R. (2005). Assessing emotional intelligence in 
ALEKSANDRA BARBARA LUBIKOWSKA

gifted and non-gifted high school students: Outcomes depend on the measure. Intelligence, 33, $369-391$. 